\title{
Self-Regulated Learning Dengan Prestasi Belajar Matematika Dan Bahasa Inggris Pada Siswa
}

\author{
Marlibi $^{1}$, Aspin $^{2}$ \& Dodi Priyatmo Silondae ${ }^{3}$ \\ Jurusan Psikologi \\ Fakultas Keguruan dan Ilmu Pendidikan, Universitas Halu Oleo \\ ibimarlibi@gmail.com ${ }^{1}$, aspin.psi@gmail.com ${ }^{2}$,dodi_silondae@uho.ac.id ${ }^{3}$
}

\begin{abstract}
Abstrak : Self-regulated learning merupakan strategri belajar yang melibatkan berbagai aspek isntrinsik dalam diri siswa untuk menunjukkan determinansi terhadap proses belajar yang ia alami. Melalui cara ini siswa dipicu untuk menentukan pilihan sendiri berbagai segi dari kegiatan belajar, mulai dari klasifikasi materi, regulasi motivasi, waktu, lingkungan sampai tujuan belajar yang hendak dicapainya. Tujuan penelitian ini adalah mengetahui hubungan self-regulated learning dengan prestasi belajar Matematika dan Bahasa Inggris pada siswa SMP Negeri 14 Kendari. Metode yang digunakan dalam penelitian ini adalah kuantitatif korelasional. Pengumpulan data dilakukan dengan menggunakan skala likert dan nilai rapor prestasi belajar dengan responden dalam penelitian ini berjumlah 43 siswa yang dipilih berdasarkan teknik simple random sampling. Hasil penelitian melalui analisis korelasi Product moment pearson menunjukkan bahwa tidak terdapat hubungan antara self-regulated learning dengan prestasi belajar matematika dan bahasa inggris pada siswa sekolah menengah pertama (SMP) Negeri 14 Kendari dengan angka koefisien korelasi sebesar 0,130 dengan nilai signifikasi sebesar 0,406. Kesimpulan dalam penelitian ini adalah tidak adanya hubungan antara self-regulated learning dengan prestasi belajar Matematika dan Bahasa Inggris pada siswa SMP Negeri 14 Kendari.
\end{abstract}

Kata kunci : prestasi belajar; self- regulated learning; siswa

\begin{abstract}
Self-regulated learning is a learning strategy that involves various intrinsic aspects in students to show the determinants of the learning process they experience. In this way students are triggered to make their own choices about various aspects of learning activities, from material classification, regulation of motivation, time, environment to the learning objectives they want to achieve. The purpose of this study was to determine the relationship between self-regulated learning and Mathematics and English learning achievement in SMP Negeri 14 Kendari. The method used in this research is correlational quantitative. The data were collected using a scale of self-regulated learning and learning achievement report cards with the respondents in this study amounting to 43 students who were selected based on simple random sampling technique. The results of this study through the pearson product moment correlation analysis showed that there was no relationship between self-regulated learning with mathematics and English learning achievement in junior high school students (SMP) Negeri 14 Kendari with a correlation coefficient of 0.130 with a significance value of 0.406. The conclusion in this study is that there is no relationship between self-regulated learning with Mathematics and English learning achievement in SMP Negeri 14 Kendari.
\end{abstract}

Keywords : learning achievement; self-regulated learning; students 


\section{Pendahuluan}

Setiap siswa memiliki keinginan untuk bisa meraih prestasi optimal. Pencapaian ini merupakan salah satu indikator siswa memperoleh kesuksesan akademik (Froiland, Oros, Smith \& Hirchet, 2012). Kesuksesan akademik itu sendiri menjadi suatu kebutuhan yang ingin dipenuhi oleh setiap siswa (Freitas \& Leonard, 2011). Ketika siswa mampu untuk mencapai prestasi akademik yang ditargetkan, maka akan mendorong munculnya kepuasan dan kenikmatan siswa dalam menjalani proses belajar. Hal ini tentunya akan memacu siswa untuk kembali mengulang perilakunya dan cenderung berupaya lebih untuk mencapai prestasi akademik yang lebih baik lagi (Pena \& Perez, 2012).

Menurut Lufri (2010) belajar merupakan suatu proses atau aktivitas individu dalam bentuk interaksi dengan lingkungannya sehingga terjadi pengalaman belajar. Setelah menempuh proses belajar, seseorang akan lebih berpengetahuan dan lebih terampil dalam kehidupan.

Siswa belajar di sekolah dengan tujuan untuk mencapai cita-cita yang diinginkan. Semua siswa pasti menginginkan prestasi yang terbaik, sehingga mereka memiliki kewajiban untuk belajar. Belajar merupakan suatu proses usaha yang dilakukan siswa untuk memperoleh suatu perubahan tingkah laku yang baru, sebagai hasil pengalamannnya sendiri dalam berinteraksi dengan lingkungannya (Slameto, 2013).

Belajar menjadi bermakna apabila siswa berperan secara aktif dalam proses belajar dan akhirnya mampu memutuskan apa yang akan dipelajari. Tanpa ada keinginan siswa untuk aktif terlibat dalam belajar, maka keberhasilan belajar tidak akan tercapai. Prestasi belajar siswa sangat diperlukan, seperti mengatur jam belajar sendiri, memilih kegiatan-kegiatan mana yang dapat menunjang prestasi akademiknya, menyusun strategi-strategi dalam belajar dan perilakuperilaku lainnya yang menandakan bahwa siswa dapat berprestasi di sekolah.

Keberhasilan dalam dunia pendidikan dapat dilihat dari hasil prestasi belajarnya. Prestasi belajar merupakan sebuah pencapaian atau tingkat keberhasilan seorang siswa dalam memahami suatu pelajaran yang dinyatakan dalam bentuk nilai setelah mengalami proses belajar mengajar. Prestasi belajar menjadi ujung dari proses belajar mengajar yang berguna untuk mengukur kemampuan siswa dalam menguasai materi (Hamdu \& Agustina, 2011).

Menurut Suryabrata (2015) terdapat dua faktor yang mempengaruhi prestasi belajar siswa, yaitu faktor internal dan faktor eksternal. Faktor internal yaitu faktor yang berasal dari individu. Faktor ini dibedakan atas faktor fisik dan non fisik. Faktor fisik di antaranya adalah kesehatan, koordinasi motorik, kondisi syaraf dan lain-lain. Sementara faktor non fisik yang mempengaruhi hasil belajar, yaitu intelegensi, rasa ingin tahu, kebutuhan akan berprestasi, dan sebagainya. Sedangkan menurut Mashilah (2011) faktor yang berhubungan dengan prestasi belajar selain penyesuaian sosial di lingkungan sekolah adalah faktor internal maupun eksternal.

Sebagaimana yang dikutip oleh Fasikhah \& Fatimah (2013) bahwa, belajar tidak hanya dikontrol oleh aspek eksternal saja, melainkan juga dikontrol oleh aspek internal yang diatur sendiri (self-regulated learning). Oleh karena itu, belajar harus dipahami sebagai proses aktif, konstruktif, dan self regulated learning. Sehingga individu yang belajar akan mendapatkan prestasi akademik yang baik, bila ia menyadari, bertanggung jawab dan mengetahui cara belajar yang efektif atau memiliki strategi regulasi diri dalam belajar (self-regulated learning) yang baik.

Berdasarkan data awal yang diambil pada tanggal 10 September 2019 melalui nilai rapor siswa, dari 215 siswa kelas VIII SMPN 14 Kendari yang tidak memenuhi kriteria ketuntasan minimal (KKM) pada mata pelajaran Bahasa Inggris yaitu 122 orang sedangkan pada mata pelajaran Matematika yang tidak memenuhi kriteria ketuntasan minimal sebanyak 130 orang. Siswa SMPN 14 Kendari memiliki berbagai macam karakter self-regulated learning diantaranya 
ada yang memiliki karakter self-regulated learning yang baik.

Berdasarkan hasil wawancara pada hari, Rabu 11 September 2019 di SMP Negeri 14 Kendari, diperoleh informasi dari salah satu guru mata pelajaran, bahwa kegiatan pembelajaran umumnya masih bersifat tradisional yaitu dengan menggunakan metode ceramah dan tanya jawab, sehingga siswa merasa bosan ketika mengikuti kegiatan belajar secara klasikal. Hal lain yang ditemui di lapangan pada saat dilakukan wawancara kepada guru BK diperoleh data bahwa siswasiswi kelas VIII belum semuanya memanfaatkan lingkungan sekitar untuk menunjang belajarnya, seperti penggunaan perpustakaan. Siswa kelas VIII yang mengunjungi perpustakaan hanya sekitar $20 \%$ dari jumlah siswa kelas VIII selebihnya tidak pernah, hal itu disebabkan karena belum ada kesadaran siswa untuk belajar mandiri.

Selain itu masih ada permasalahan belajar yang ditemukan pada saat dilakukan wawancara kedua pada tanggal 12 September 2019 mencakup perilaku siswa-siswi di SMP Negeri 14 Kendari khususnya pada kelas VIII. Sekitar 5 siswa dalam satu kelas yang minat belajarnya sangat kurang pada beberapa mata pelajaran, sehingga pada saat jam pelajaran berlangsung siswa tersebut tidak mengikuti pelajaran dengan baik dan sering meninggalkan kelas tanpa sepengetahuan guru. Beberapa dijumpai siswa-siswi di kantin pada saat jam pelajaran, dan pada saat dilakukan wawancara dengan 2 orang siswa yang berada di kantin, mengaku kesulitan dalam pelajaran hitung-hitungan. Hal itu membuat siswa tidak mengerti materi apa saja yang telah disampaikan oleh guru, sehingga menyebabkan prestasi belajarnya rendah.

Penelitian yang dilakukan oleh Ahmed, Werf, Kuyper \& Minnaert (2013) mengenai hubungan emosi dan selfregulated learning dengan prestasi Matematika menunjukkan bahwa ketika seseorang dalam emosi positif, ia akan melakukan self-regulated learning dengan baik. Self-regulated learning ini akan berpengaruh pada prestasi belajar Matematika siswa. Siswa yang mampu melakukan pengelolaan diri dalam belajarnya dengan baik akan berdampak pada prestasi Matematika tinggi. Hasil penelitian ini menyatakan bahwa terdapat korelasi positif yang signifikan antara selfregulated learning dengan prestasi belajar Matematika.

Munjono (2010) menyatakan bahwa prestasi belajar adalah hasil suatu aktivitas belajar yang dilakukan berdasarkan pengukuran dan penilaian terhadap hasil pendidikan di sekolah secara umum diwujudkan ke dalam angka-angka dalam rapor. Dimana dalam hasil observasi langsung yang diamati siswa yang berprestasi pada tanggal 12 September 2019 mereka sangat tekun dalam belajar dan mampu mengerti apa yang diajarkan oleh guru, oleh karena itu siswa yang berprestasi mampu melaksanakan self-regulated learning yang baik seperti melakukan perencanaan belajar yang baik, tujuan belajar yang baik sehingga mampu melaksanakan dan menjawab hasil evaluasi belajar yang diberikan oleh guru.

Alfina (2014) mendefiniskan selfregulated learning sebagai suatu keadaan individu yang belajar sebagai pengendali aktivitas belajarnya sendiri, pengendali motivasi dan tujuan akademik, pengelola sumber belajar, serta menjadi pelaku dalam pengambilan keputusan dan pelaksana dalam proses belajar. Self-regulated learning juga didefinisikan sebagai bentuk belajar individual dengan bergantung pada motivasi belajar mereka, secara otonomi mengembangkan pengukuran (kognisi, metakognisi dan perilaku dan memonitor kemauan belajarnya (Latipah, 2010).

Hal yang sama-sama ditekankan dalam kedua definisi di atas adalah referensi keberhasilan mencapai tujuan dalam belajar utamanya ditentukan dari diri siswa sendiri, dan bukan oleh pendidik dengan ini diindikasikan bahwa strategi yang diterapkan oleh para siswa dalam mencapai prestasi belajar yang baik bisa saja berbeda-beda, yaitu dengan cara 
proses belajar yang baik, namun siswa yang dalam upaya belajarnya memenuhi karakteristrik tertentu dapat dikatakan mempraktikkan self-regulated learning.

Siswa yang memiliki self-regulated learning diantaranya menunjukkan karakteristik seperti memiliki strategi untuk mengelola emosi, secara periodik memonitor kemajuan ke arah tujuan, menyesuaikan dan memperbaiki strategi berdasarkan kemajuan yang telah dibuat, hal ini menunjukkan bahwa kemampuan self-regulated learning begitu penting bagi siswa (Nurfiani, 2015). Siswa akan mengalami pertambahan prestasi yang signifikan di dalam lingkungan pembelajaran dengan adanya peningkatan kemandirian belajar (Vrieling, Bastiens, \& Stijnen, 2012).

Rumusan masalah dalam penelitian ini yaitu apakah terdapat hubungan selfregulated learning dengan pretasi belajar Matematika dan Bahasa Inggris pada siswa.

Berdasarkan rumusan masalah yang telah diuraikan, adapaun tujuan yang ingin dicapai dalam penelitian ini adalah apakah terdapat hubungan self-regulated learning dengan prestasi belajar Matematika dan Bahasa Inggris pada siswa.

Hipotesis yang diajukan dalam penelitian ini adalah terdapat hubungan antara self-regulated learning dengan prestasi belajar Matematika dan Bahasa Inggris pada siswa.

\section{Metode penelitian}

Penelitian ini merupakan penelitian kuantitatif dengan menggunakan desain penelitian korelasional. Variabel dalam penelitian ini adalah self-regulated learning sebagai variabel bebas dan variabel prestasi belajar sebagai variabel terikat. Populasi dalam penelitian ini adalah seluruh siswa kelas VIII SMPN 14 Kendari yang berjumlah 215 orang. Teknik pengambilan sampel dilakukan dengan teknik simple random sampling sehingga didapatkan sampel sebanyak 43 siswa.

Definisi operasional mengenai variabel penelitian ini adalah Self-regulated learning merupakan kondisi atau aktifitas belajar individu dimana dalam proses belajarnya individu tersebut menjadi penentu aktivitas, motivasi, kongnisi, tingkah laku serta menjadi pengambil keputusan agar aktivitas belajar tersebut sesuai dengan kondisi lingkungan serta tujuan yang ingin dicapainya. Dalam penelitian self-regulaated learning diukur menggunakan skala self-regulated learning yang terdiri dari 3 fase yakni perencanaan belajar, pelaksanaan belajar dan evaluasi belajar. Sedangkan prestasi belajar adalah penilaian guru yang diberikan kepada siswa berdasarkan proses belajar dan hasil evaluasi belajar yang dilakukan. Untuk mengetahui dapat dilihat dari nilai rata-rata masing-masing pelajaran dalam penelitian ini difokuskan pada nilai rata-rata mata pelajaran Matematika dan Bahasa Inggris.

Instrumen pengumpulan data dalam penelitian ini menggunakan skala selfregulated learning yang berjumlah 54 aitem, sedangkan untuk mengukur prestasi belajar peneliti menggunakan nilai raport yang didapatkan oleh masing-masing siswa yang menjadi responden. Validitas skala penelitian ini menggunakan koefisien validitas isi Aiken's V yang dirumuskan untuk menghitung content-valid coefficient yang didasari oleh penilaian para ahli. Hasil uji coba skala self-regulated learning menunjukkan bahwa dari 54 item yang telah dianalisis, 39 item dinyatakan valid sedangkan 15 item lainnya dikatakan gugur karena tidak memenuhi standar koefisien korelasi yang telah ditetapkan yakni $\geq 0,263$. Penelitian ini menggunakan SPSS (Statistical Package for the Social Sciences) versi 24.0 untuk mengetahui nilai reliabilitas dengan melihat skor Cronbach's alpha. Adapun nilai reliabilitas skala self-regulated learning adalah 0,890 .

Penelitian ini menggunakan analisis deskriptif untuk memberikan deskripsi mengenai data dari variabel yang diukur. Untuk mengetahui apakah data terdistribusi secara normal yakni menggunakan teknik Kolmogorov Smirnov, uji linearitas menggunakan test from linearity, serta 
pengujian hipotesis menggunakan teknik Korelasi Product Moment Pearson dengan menggunakan SPSS (Statistical Package for the Social Sciences) versi 24.0.

\section{Hasil Penelitian dan Pembahasan}

Pada tabel di bawah ini, dapat diketahui bahwa sampel penelitian berjumlah 43 siswa kelas VIII SMPN 14 Kendari. Pada variabel self-regulated learning diketahui nilai minimum yang diperoleh sama dengan 76 , nilai maksimum sama dengan 125 dengan mean yang diperoleh sama dengan 106,19 sehingga diperoleh nilai standar deviasi sebesar 13,741 . Sedangkan pada variabel prestasi belajar diketahui nilai minimum yang diperoleh sama dengan 61, nilai maksimum sama dengan 83 dengan mean yang diperoleh sama dengan 68,90 sehingga diperoleh nilai standar deviasi sebesar 6,110.

Tabel 1. Data deskriptif penelitian

\begin{tabular}{cccccc}
\hline Variabel & $\mathrm{N}$ & $\min$ & $\max$ & mean & $\begin{array}{c}\text { Standar } \\
\text { deviasi }\end{array}$ \\
\hline $\begin{array}{c}\text { Self- } \\
\text { regulated }\end{array}$ & 43 & 76 & 125 & 106,19 & 13,741 \\
$\begin{array}{c}\text { learning } \\
\text { Prestasi } \\
\text { Belajar }\end{array}$ & 43 & 61 & 83 & 68,90 & 6,110 \\
\hline
\end{tabular}

Deskriptif data penelitian di atas dapat dijadikan dasar dalam pengkategorian sampel penelitian. Tujuan dari kategorisasi ini untuk menempatkan subjek ke dalam kelompok-kelompok yang berjenjang, menurut rangkaian berdasarkan atribut yang diukur (Azwar, 2017).

Berdasarkan data tabel di bawah ini, ditemukan bahwa dari 43 subjek, terdapat 6 subjek yang memiliki tingkat kategori selfregulated learning yang tinggi dengan persentase $14,0 \%$, subjek dengan persentase $53,5 \%$ dalam kategori sedang dan 14 subjek dalam kategori rendah dengan persentase $32,6 \%$.
Tabel 2. Kategorisasi Self-regulated learning

\begin{tabular}{cccc}
\hline Kategori & Skor & $\mathrm{N}$ & Persentase \\
\hline Tinggi & $119,931>\mathrm{X}$ & 6 & $14,0 \%$ \\
Sedang & $-92,449 \leq \mathrm{X} \leq$ & 23 & $53,5 \%$ \\
& 119,931 & & \\
Rendah & $\mathrm{X}<-92,449$ & 14 & $32,6 \%$ \\
Jumlah & & 43 & $100 \%$ \\
\hline
\end{tabular}

Berdasarkan data tabel di bawah ini, ditemukan bahwa dari 43 subjek, terdapat 10 subjek yang memiliki tingkat kategori prestasi belajar yang tinggi dengan persentase $23,3 \%$, subjek dalam kategori sedang sebanyak 7 subjek dengan persentase $16,3 \%$, dan 26 subjek dalam kategori rendah dengan persentase $60,5 \%$.

Tabel 3. Kategorisasi Prestasi Belajar

\begin{tabular}{cccc}
\hline Kategori & Skor & $\mathrm{N}$ & Persentase \\
\hline Tinggi & $75,01>\mathrm{X}$ & 10 & $23,3 \%$ \\
Sedang & $-62,79 \leq \mathrm{X} \leq$ & 7 & $16,3 \%$ \\
& 72,01 & & \\
Rendah & $\mathrm{X}<-62,79$ & 26 & $60,5 \%$ \\
Jumlah & & 43 & $100 \%$ \\
\hline
\end{tabular}

Uji normalitas terhadap variabel selfregulated learning siswa diperoleh nilai signifikansi $(p)=0,094>0,05$, nilai tersebut memiliki arti bahwa variabel selfregulated learning berdistribusi normal.

Selanjutnya, hasil uji normalitas variabel prestasi belajar di ketahui memiliki nilai signifikansi $(p)=0,051>0,05$, sehingga berarti bahwa variabel prestasi belajar juga berdistribusi normal.

Tabel 4. Uji Normalitas

\begin{tabular}{ccc}
\hline Variabel & Signifikansi & Keterangan \\
\hline SRL & 0.094 & $\mathrm{P} \geq 0,05$ (Normal) \\
Prestasi Belajar & 0.051 & $\mathrm{P} \geq 0,05$ (Normal) \\
\hline
\end{tabular}

Uji linearitas data dengan menggunakan uji compare means data yang dihasilkan yakni $0,420>0,05$. Hasil tersebut menyimpulkan bahwa adanya hubungan yang linear antara self-regulated learning dengan prestasi belajar siswa. 
Tabel 5. Uji Linearitas

\begin{tabular}{ccc}
\hline Variabel & Sig. Linearity & $\begin{array}{c}\text { Sig.Deviation } \\
\text { From Linearty }\end{array}$ \\
\hline $\begin{array}{c}\text { Self-regulated } \\
\text { learning } \\
\text { Prestasi Belajar }\end{array}$ & 0.420 & 0.865 \\
\hline
\end{tabular}

Analisis data dengan menggunakan teknik korelasi Pearson Product moment dengan menggunakan bantuan program SPSS versi 24.0 diperoleh angka koefisien korelasi sebesar 0,130 dengan nilai signifikansi sebesar 0,406 maka hipotesis tidak ada hubungan antara self-regulated learning dengan prestasi belajar Matematika dan Bahasa Inggris pada siswa SMPN 14 Kendari ditolak artinya bahwa variabel self-regulated learning dan prestasi belajar siswa tidak memiliki korelasi.

Tabel 6. Uji Korelasi Product Moment

\begin{tabular}{ccc}
\hline Variabel & Korelasi Pearson & Signifikansi \\
\hline $\begin{array}{c}\text { Self-regulated } \\
\text { learning }\end{array}$ & 0.130 & 0.406 \\
Prestasi Belajar & 0.130 & 0.406 \\
\hline
\end{tabular}

Penelitian ini dilakukan dengan tujuan untuk mengetahui apakah ada hubungan antara self-regulated learning dengan prestasi belajar siswa. Berdasarkan hasil uji korelasi antara self-regulated learning dan prestasi belajar menunjukkan bahwa tidak ada hubungan antara kedua variabel tersebut.

Siswa akan memiliki self-regulated learning yang sedang apabila siswa masih kurang dalam mengatur penggunaan waktu saat menyelesaikan tugas dan kurang melakukan evaluasi yang baik dalam belajar. Kemudian seseorang yang mempunyai self-regulated learning rendah ketika siswa kurang mampu untuk motivasi diri sendiri dan kurang menggunakan berbagai cara yang memungkinkan mereka untuk mencapai tujuan belajar yang diinginkan. Dalam hal ini, tujuan belajar subjek adalah prestasi belajar. Siswa yang kurang memiliki self-regulated learning, tentu kurang memiliki pengetahuan dan keterampilan tentang berbagai cara yang dapat digunakan untuk meningkatkan belajarnya.
Christopher, Paul \& Stuart (2003) mendefinisikan self-regulated learning merupakan proses konstruktif aktif dimana siswa menetapkan tujuan belajarnya dan kemudian berusaha untuk memonitor, mengatur, dan mengontol kognisi, motivasi dan tingkah lakunya agar sesuai dengan tujuannya dan kondisi kontekstual dari lingkungannya. Sedangkan Schunk (2009) mengemukakan bahwa karakteristik yang dimiliki oleh Self-regulated learning yaitu individu yang memiliki kemampuan untuk aktif dalam mengatur aktivitas belajarnya dengan berbagai cara.

Hasil penelitian ini sejalan dengan penelitian sebelumnya oleh Supriyanto (2015) yang berjudul "Hubungan selfregulated learning dan prestasi akademik pada mahasiswa semester pertama Prodi Psikologi Universitas Pembangunan Jaya". Hasil penelitian menunjukkan tidak ada hubungan signifikan antara self-regulated learning dan prestasi akademik pada mahasiswa semester pertama prodi Psikologi Universitas Pembangunan Jaya.

Hasil penelitian relevan dengan penelitian sebelumnya oleh Sari (2016) yang berjudul "Hubungan antara self-efficacy dan self-regulated learning dengan prestasi belajar akademik pada mahasiswa Fakultas Psikologi Universitas Surabaya". Hasil penelitian menunjukkan bahwa ada hubungan selfefficacy dengan prestasi akademik $(\mathrm{r}=0,234 \mathrm{p}$ $=0,036<0,05)$ dan tidak adanya hubungan antara self-regulated learning dengan prestasi akademik $(r=0,072, p=0,526>0,05)$.

Penelitian lain juga yang memiliki hasil yang relevan adalah penelitian Putry, Armen \& Putri (2017) yang berjudul "Hubungan Kemampuan self-regulated learning dengan Hasil Belajar IPA Siswa SMPN 3 Padang”. Hasil penelitian tersebut menunjukkan bahwa secara keseluruhan profil kemampuan selfregulated learning siswa SMPN 3 Padang, berada pada taraf kategori sedang $(71,99 \%)$ dan aspek kemampuan self-regulated learning yang paling menonjol adalah motivasi ekstrinsik (88,29\%). Berdasarkan hasil analisis, diperoleh nilai $r$ sebesar 0,01 dengan interptestasi hubungan sangat lemah (tidak 
berkorelasi). Kontribusi kemampuan selfregulated learning siswa terhadap hasil belajar kongnitif IPA siswa hanya sebesar $1 \%$. Sedangkan sisanya berkisar $99 \%$ hasil belajar kognitif siswa dipengaruhi oleh faktor-faktor lain.

Hasil penelitian juga didukung Hastuti \& Yeonanto (2018) yang berjudul "Pengaruh self-regulated learning, kecemasan matematika, dukungan sosial guru matematika dan dukungan sosial teman sebaya terhadap prestasi belajar siswa SMP Negeri "X" Surabaya". Hasil penelitian menunjukkan bahwa dari dari hasil uji $\mathrm{t}$ variabel self-regulated learning dan dukungan sosial teman sebaya secara parsial tidak berpengaruh secara signifikan terhadap prestasi belajar Matematika.

Hasil penelitian dilakukan oleh Saraswati (2020) yang berjudul "Kontribusi self-regulated learning dan kecerdasan emosi dalam konsentrasi belajar". Hasil penelitian menunjukkan tidak ada hubungan antara selfregulated learning dan konsentrasi belajar $\mathrm{r}=$ $-0,079$ ( $>>0,05)$, tidak ada hubungan antara kecerdasan emosi dan konsentrasi belajar $\mathrm{r}=$ $0,677(\mathrm{p}>0,05)$ dan terdapat hubungan positif self-regulated learning dan kecerdasan emosi $r=0,496(p<0,05)$. Dengan demikian, berarti semakin tinggi self-regulated learning maupun kecerdasan emosi yang dimiliki seseorang tidak berhubungan secara signifikan dengan konsentrasi belajar yang dimilikinya. Oleh karena itu, self-regulated learning dan kecerdasan emosi tidak memiliki kontribusi yang signifikan terhadap konsentrasi belajar pada penelitian ini.

Berdasarkan teori yang telah dipaparkan di atas dan penelitian-penelitian sejalan terlihat bahwa tidak ada hubungan selfregulated learning dan konsentrasi belajar, hal tersebut sejalan dengan hasil uji hipotesis yang memiliki koefisien korelasi yang bernilai positif sebesar 0,130 . Namun, nilai signifikan antara dua variabel tersebut sebesar 0,406 hal ini menunjukkan bahwa tidak adanya hubungan yang signifikan antara selfregulated learning dengan prestasi belajar Matematika dan Bahasa Inggris pada siswa SMPN 14 Kendari.

\section{Kesimpulan}

Berdasarkan data penelitian maka disimpulkan bahwa hipotesis dalam penelitian ini tidak diterima. Dari hasil analisis data yang ditemukan bahwa tidak ada hubungan antara self-regulated learning dengan prestasi belajar pada siswa SMPN 14 Kendari.

Analisis deskriptif juga menjelaskan bahwa self-regulated learning dan prestasi belajar pada siswa paling banyak dialami pada kategori yang sedang dan rendah.

\section{Daftar Pustaka}

Ahmed, W., Werf, D. V. G., Kuyper. H \& Minnaert, A. (2013). Emotions, self-regulated learning, and achievement in mathematics: A growth curve analysis. Journal of Educational Psychology. 105 (1), 150-161.

Alfina, I. (2014). Hubungan self-regulated learning dengan proklatinasi akademik pada siswa akselerasi. Jurnal Psikoborneo. 2 (1), 60-66.

Azwar. (2017). Metode penelitian psikologi. Yogyakarta: Pustaka Pelajar .

Christopher, A. W., Paul, P. P \& Stuart, A. K. (2003). Paper prepared for the conference on indicator of positive development: definitions, measures and prospestive validity. Sponsored by child trends, National Instituces of Health.

Fasikhah, S. S \& Fatimah, S. (2013). Selfregulated learning (SRL) dalam meningkatkan prestasi akademik pada mahasiswa. Jurnal Ilmiah Psikologi Terapan, 1 (1), 145-155. 
Freitas, A. F \& Leonard, J. L. (2011). Maslow's hierarchy of needs and student academic success. Teaching and Learning in Nursing. 6 (1), 9-13.

Froiland. M. J., E. Oros., L. Smith \& T. Hirchet. (2012). Instrinsic motivation to learn: the nexus between psychological health anda academic success. Contemporary School Psychology. 16 (1), 91-101.

Hamdu, G., \& Agustina, L. (2011). Pengaruh motivasi belajar siswa terhadap prestasi belajar IPA di Sekolah Dasar, Jurnal Penelitian Pendidikan. 12 (1), 90-96.

Hastuti, H.W \& Yoenanto, H.N. (2018). Pengaruh self-regulated learning, kecemasan matematika, dukungan sosial guru matematika dan dukungan sosial teman sebaya terhadap prestasi belajar siswa SMP Negeri "X" Surabaya. Jurnal Psikologi Integratif. $6(2), 116-130$.

Latipah, E. (2010). Strategi self-regulated learning dan prestasi belajar: Kajian meta analisis. Jurnal Psikologi. 37 (1), 110-129.

Lufri. 2010. Strategi pembelajaran biologi. Padang: UNP Press.

Mashilah, S. (2011). Studi tentang hubungan dukungan sosial, penyesuaian sosial di lingkungan sekolah dan prestasi akademik siswa SMIPT Assyfa Boarding School Subang Jawa Barat. Jurnal Psikologi Undip. 10 (2), 103-114.

Munjono. (2010). Prestasi belajar siswa. Jakarta: UNY Pres.

Nurfiani, H. (2015). Survei kemampuan selfregulated learning (SRL) siswa kelas X SMK Negeri 1 Kalasan. Skripsi tidak diterbitkan. Fakultas Ilmu
Pendidikan. Universitas Negeri Yogyakarta.

Pena, L. D. C., T. M \& Perez, J. (2012). Continuous assessment improved academic achievement and satisfaction of psychology students in Spain. Teaching of Psychology. 39 (1), 45-47.

Putry, D. N., Armen \& Putri, H, D. (2017). Hubungan kemampuan self-regulated learning dengan hasil belajar IPA siswa SMPN 3 Padang. Jurnal Biosains. 1 (2), 210-216.

Saraswati, P. (2020). Kontribusi selfregulated learning dan kecerdasan emosi dalam konsentrasi belajar. Jurnal Psikologi. 1 (2), 102-120.

Sari, A. D. (2016). Hubungan antara selfefficacy dan self-regulated learning dengan prestasi belajar akademik pada mahasiswa Fakultas Psikologi Universitas Surabaya. Jurnal Ilmiah Mahasiswa Universitas Surabaya. 5 (1), 1-14.

Schunk, D. H. (2009). Learning theories an educational perpective. Social cognitive theory. London: Person Educational LTD.

Slameto. (2013). Belajar dan faktor-faktor yang mempengaruhinya. Jakarta: PT Rineka Cipta.

Supriyanto. (2015). Hubungan antara selfregulated learning dan prestasi akademik pada mahasiswa semester pertama Prodi Psikologi. Universitas Pembangunan Jaya. Jurnal Universitas Pembangunan Jaya. 2 (2), 49-61.

Suryabrata. (2015). Faktor yang mempengaruhi prestasi belajar. Universitas Negeri Yogyakarta. 
Jurnal Sublimapsi

e-ISSN 2716-1854

2 (2), (Mei) 2021, 71-79

p-ISSN 2720-930X

Vrieling, E., Bastiens, T., \& Stijnen, S. (2012). Effects of increased selfregulated learning opportunities on student teachers' motivation and use of metacongnitive skills. Australian Journal of Teacher Education. 37, (8), 102-117. 